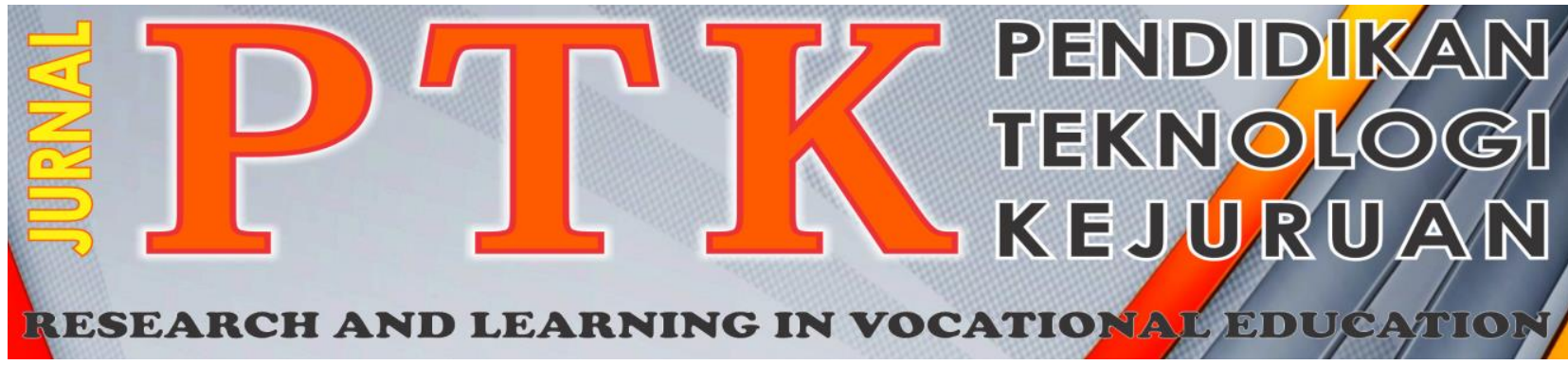

Vol. 1, No. 2 Mei 2018

P-ISSN: 2621-3273

E-ISSN: 2621-1548

\title{
PENERAPAN MEDIA PEMBELAJARAN EDMODO \\ UNTUK MENINGKATKAN MOTIVASI AKTIVITAS INTELEKTUAL PADA MAHASISWA PENDIDIKAN TEKNIK ELEKTRO UNIVERSITAS PGRI MADIUN
}

\author{
Vinanda U'un Ayuningtyas \\ Pendidikan Teknik Elektro Universitas PGRI Madiun \\ *Corresponding author, e-mail: uunayuvinanda@gmail.com
}

\begin{abstract}
Abstrak-Edmodo merupakan media pembelajaran yang berbasis internet, yang diwajibkan untuk Mahasiswa di dalam kelas maupun diluar kelas untuk mendukung proses belajar mengajar. Penelitian ini bertujuan untuk: 1) mengetahui hasil belajar mahasiswa Pendidikan Teknik Elektro Universitas PGRI Madiun khususnya untuk Mahasiswa semester 3 (tiga), 2) memperbaiki aktivitas intelektual dalam bidang IT mahasiswa yang belum digunakan secara efektif. Metode penelitian yang digunakan dalam penelitian ini adalah metode eksperimen dengan bentuk kuasi eksperimen. Pre test dilakukan diawal penelitian dan Post test dilakukan diakhir penelitian baik terhadap kelas eksperimen maupun kontrol. Berdasarkan tabel diatas skor N-Gain kelas kontrol yang belum menggunakan media pembelajaran kategori rendah, sedangkan kelas eksperimen yang mendapatkan perlakuan menggunakan media pembelajaran Edmodo termasuk dalam kategori sedang. Jadi dapat disimpulkan bahwa implementasi media pembelajaran Edmodo dapat memotivasi aktifitas intelektual sehingga mahasiswa tertarik dan ingin terus belajar dengan dibuktikan hasil belajar meningkat. Kesimpulan tersebut dapat menjadi pertimbangan dalam guru menggunakan media pembelajaran dan melaksanakan proses kegiatan belajar mengajar di dalam kelas.
\end{abstract}

\section{Kata kunci : Edmodo, Pretest, Posttest, Hasil Belajar}

Abstract-Edmodo was cloud-based learning media, which are required for students in the classroom and outside the classroom to support the teaching and learning process. This research aims to know the results: 1) student learning Electrical Engineering Education University PGRI Madiun especially for students third students(3), 2) improve intellectual activity in the field of IT students who haven't used effective. Research methods used in this research is a method of experimentation with the form quasi experiments. Pre test conducted early research and Post test conducted at the end of the research to the classroom experiments as well as control. Based on the table above score n-Gain control classes that have yet to use the learning media category is low, while the class of experimental treatment using Edmodo learning media is included in the category of being. So it can be concluded that the implementation of the learning media Edmodo can motivate the intellectual activities so that students are interested and would like to continue learning with proven results of learning increases. The conclusion can be a consideration in teachers using media learning and implementing the process of teaching and learning activities in the classroom.

Keywords： Edmodo, Pretest, Posttest, Learning Outcomes

Copyright (c) 2018 JPTK. All rights reserved

\section{Pendahuluan}

Informasi dan teknologi atau yang sering kita dengar dengan IT, merupakan salah satu media pembelajaran yang sangat efektif untuk mentransfer/menyampaikan materi perkuliahan dosen kepada peserta didik. Sebelum menggunakan media teknologi informasi ataupun metode/model pembelajaran langsung, yang rata-rata mahasiswa 
merasa jenuh dan bosan tidak ada variasi untuk pembelajaran.

Media pembelajaran berbasis internet atau $E$ Learning saat ini banyak digunakan untuk kegiatan belajar mengajar. Salah satu media yang dapat digunakan untuk menunjang kegiatan dalam pembelajaran yaitu Edmodo. Edmodo adalah platform media sosial yang sering digambarkan seperti Facebook untuk sekolah dan dapat berfungsi lebih banyak lagi sesuai kebutuhan [1][2]. Edmodo merupakan media yang menarik bagi Dosen dan peserta didik dengan elemen sosial yang menyerupai Facebook. Seorang Dosen dapat dengan mudah mengelola sebuah sistem yang menyediakan fitur terbaik dan praktis, sehingga Dosen selalu terhubung dengan peserta didik dan mengatur aktivitas peserta didik dengan mudah. Kegiatan pembelajaran yang dapat digunakan sesuai dengan fitur yang tersedia pada media[3] Edmodo yakni content sharing atau berbagi materi pelajaran, penugasan, kuis, polling serta memungkinkan adanya kegiatan diskusi pada fitur komentar.

Aktivitas merupakan prinsip atau asas yang sangat penting dalam interaksi belajar mengajar [4] [5]. Pembelajaran akan menghasilkan suatu perubahan dan peningkatan kemampuan pengetahuan serta keterampilan pada diri peserta didik. Aktivitas belajar memiliki beberapa jenis dan indikator dimana pada penelitian ini dipilih 6 indikator berdasarkan penggunaan media Edmodo. Indikator-indikator yang akan digunakan yaitu, (1) mengunduh bahan ajar, (2) merumuskan pertanyaan, (3) mengunggah hasil pekerjaan ke dalam Edmodo, (4) memberikan tanggapan pada fitur polling, (5) mengerjakan soal yang diberikan Dosen dan (6) mengumpulkan tugas tepat pada waktunya. Menurut Hamalik hasil belajar adalah sebagai terjadinya perubahan tingkah laku pada diri seseorang yang dapat diamati dan diukur dalam bentuk pengetahuan, sikap, dan keterampilan [6]

Berdasarkan latar belakang dan hasil pengamatan dari dosen dan mahasiswa di Universitas PGRI Madiun khususnya jurusan Pendidikan Teknik Elektro saat ini model/metode pembelajaran yang digunakan pembelajaran langsung yang berpusat pada dosen saja yang membuat mahasiswa merasa jenuh, bosan, dan mengantuk. Untuk fasilitas Wifi/internet di Kampus Universitas PGRI Madiun sangat memadai tetapi belum dimanfaatkan dengan maksimal, belum ada umpan baliknya melalui internet/online. Maka atas dasar itu penulis melakukan penelitian penerapan media pembelajaran edmodo untuk meningkatkan motivasi aktivitas intelektual pada mahasiswa Pendidikan Teknik Elektro Universitas PGRI Madiun.

\section{METODE}

Metode yang digunakan dalam penelitian ini adalah metode eksperimen semu (Quasi Experiment). Eksperimen semu adalah jenis komparasi yang membandingkan pemberian suatu perlakuan (treatment) pada suatu objek (kelompok eksperimen) serta melihat besar pengaruh perlakuannya [4]. Penelitian ini menggunakan Pretest - Posttest Control Group Design. Teknik pengumpulan data yang digunakan untuk penelitian ini berupa instrumen tes tersebut untuk mengukur kemampuan mahasiswa sebelum dan setelah dilakukan proses pembelajaran. Instrumen test yang diberikan kepada mahasiswa berjumlah 20 soal. Subjek penelitian ini adalah Mahasiswa Semester tiga kelas A sebanyak 13 mahasiswa dan mahasiswa semester satu kelas B sebanyak 13 mahasiswa pada jurusan Pendidikan Teknik Elektro. Selanjutnya, hasil pretest dan hasil posttest menggunakan skor $N$ gain sehingga diperoleh hasil perbedaan nilai siswa pada saat sebelum dilakukan eksperimen dan setelah dilakukan eksperimen. Desain penelitiannya dapat digambarkan sebagai berikut;

\begin{tabular}{lccc}
\hline Kelompok & Pretest & Perlakuan & Postest \\
\hline Kontrol & $\mathrm{T} 1$ & $\mathrm{X}$ & $\mathrm{T} 2$ \\
\hline Eksperimen & $\mathrm{T} 2$ & - & $\mathrm{T} 2$ \\
\hline
\end{tabular}

Keterangan:

T1 : Pretest

T2 : Postest

$\mathrm{X}$ : Perlakuan (treatment)

$$
\text { N-Gain }=\frac{\text { Tpost }- \text { Tpretest }}{\text { Tmaks }- \text { Tpretest }}
$$

Keterangan :

$\mathrm{N}$-Gain = Indeks gain

Tposttest $=$ perolehan skor setelah perlakuan

Tpretest $=$ perolehan skor sebelum perlakuan

Dengan kriteria penskoran dapat dilihat pada tabel di bawah ini:

Tabel 1. Kriteria penskoran N-Gain

\begin{tabular}{ccc}
\hline No. & $\begin{array}{c}\text { Kategori perolehan N- } \\
\text { Gain }\end{array}$ & Keterangan \\
\hline 1 & $0,70>$ N-Gain & Tinggi \\
\hline 2 & $0,30<=$ N-Gain $<=0,70$ & Sedang \\
\hline 3 & N-Gain $<0,30$ & Rendah \\
\hline
\end{tabular}

Diadaptasi dari Hake (1999)

\section{HASIL DAN PEMbahaSAN}

Berdasarkan penelitian yang telah dilakukan pada kelas kontrol dan kelas eksperimen, diperoleh 
data sebelum penelitian dan setelah penelitian dilakukan. Menurut hasil penelitian bahwa rata-rata Pretest dan Posttest kelas eksperimen lebih tinggi dibandingkan kelas kontrol yang belum menggunakan media pembelajaran Edmodo dapat dilihat pada tabel dan bagan di bawah ini:

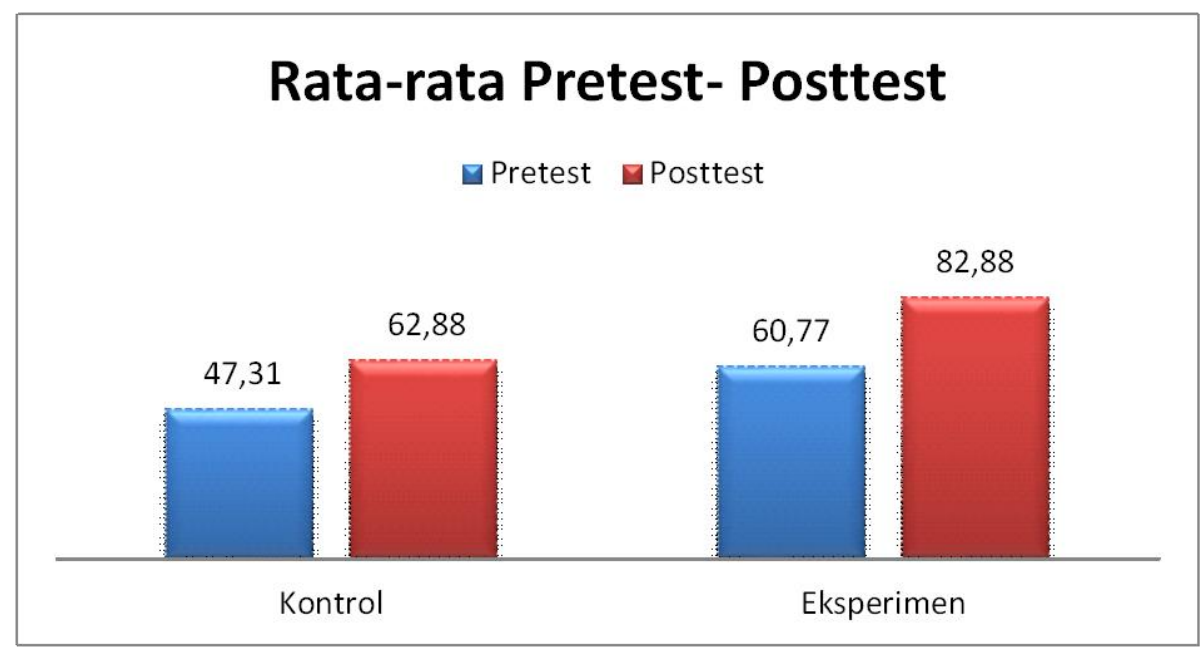

Gambar 1. Rata-rata Pretest-Postest

Di bawah ini bagan yang menunjukkan ratarata skor gain dari kelas kontrol dan kelas eksperimen, bisa dilihat bahwa perbandingan untuk kelas kontrol mendapat skor 15,58 dan kemudian meningkat kelas eksperimen menjadi 29,04. Untuk berikutnya hasil belajar dan motivasi mahasiswa bisa dilihat pada tabel di atas dan bagan dibawah ini, bahwa kelas eksperimen mendapatkan skor 0,58 dengan kategori sedang dan kelas kontrol mendapatkan skor 0,29 dengan kategori rendah.
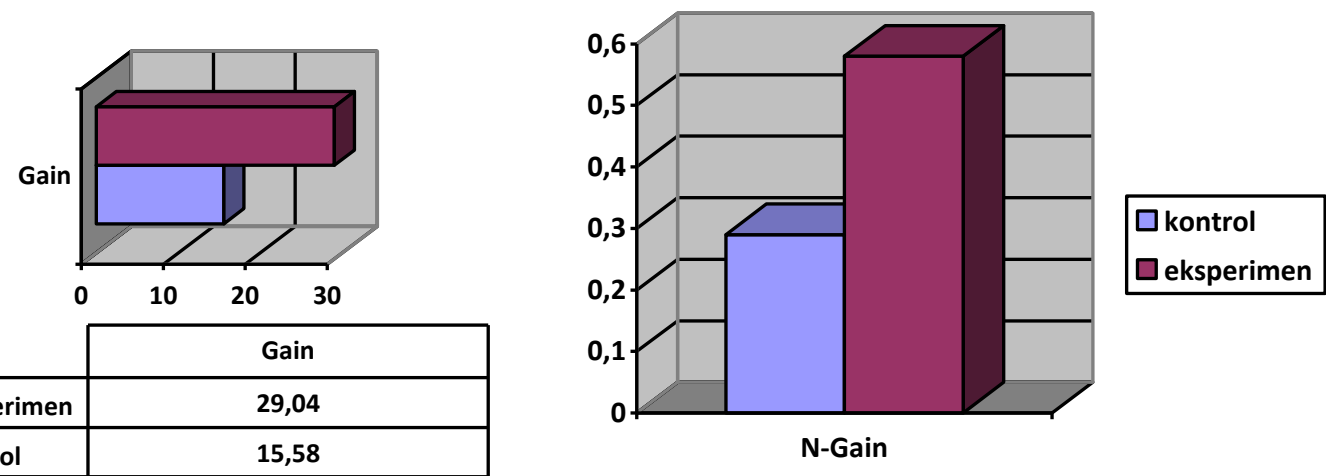

Gambar 2. Rata-Rata Skor Gain dari Kelas Kontrol dan Kelas Eksperimen

Berikut hasil belajar yang sudah dihitung berdasarkan metode penelitian ;

\begin{tabular}{lccccc}
\hline \multicolumn{1}{c}{ Kelas } & Pretest & Posttest & Gain & N-Gain & $\begin{array}{c}\text { Interpretasi } \\
\boldsymbol{N} \text {-Gain }\end{array}$ \\
\hline Kontrol & 47.31 & 62.88 & 15.58 & 0.29 & Rendah \\
\hline Eksperimen & 58.08 & 87.12 & 29.04 & 0.58 & Sedang \\
\hline
\end{tabular}

Berdasarkan tabel di atas skor N-Gain kelas kontrol yang belum menggunakan media pembelajaran kategori rendah, sedangkan kelas eksperimen yang mendapatkan perlakuan menggunakan media pembelajaran Edmodo termasuk dalam kategori sedang. Jadi dapat disimpulkan bahwa implementasi media pembelajaran Edmodo dapat memotivasi aktifitas intelektual sehingga mahasiswa tertarik dan ingin terus belajar dengan dibuktikan hasil belajar meningkat.

Berikut hasil dari implementasi menggunakan media pembelajaran Edmodo 


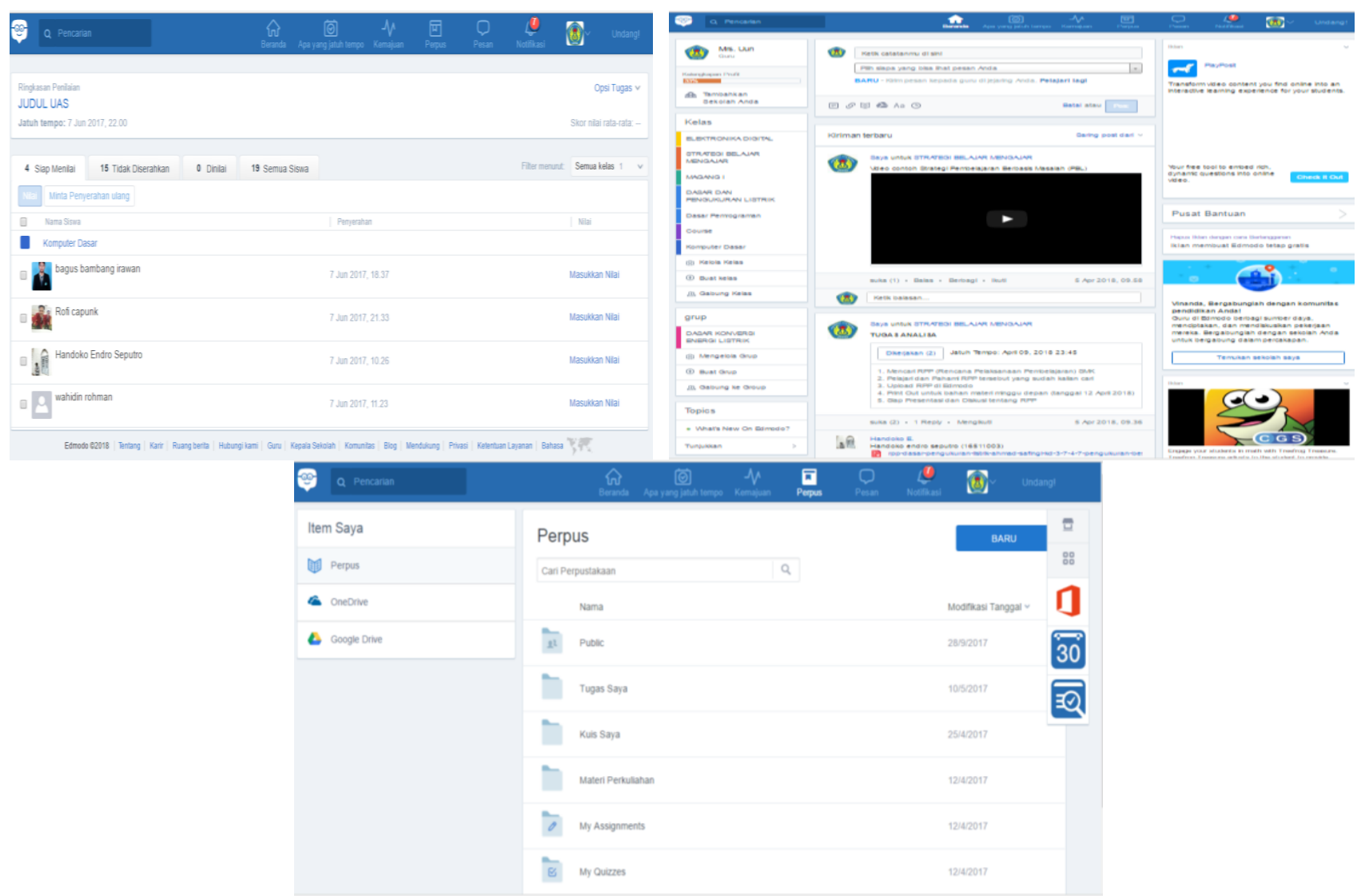

Gambar 3. Hasil dari implementasi menggunakan media pembelajaran Edmodo

\section{KESIMPULAN}

Berdasarkan hasil analisis dan pembahasan data penelitian yang telah dilakukan oleh peneliti, dapat disimpulkan bahwa penggunaan media pembelajaran e-learning berbasis Edmodo dapat meningkatkan hasil belajar mahasiswa, dengan dibuktikan hasil analisis bahwa kelas kontrol/kelas yang menggunakan pembelajaran langsung/konvensional kategori rendah, sedangkan kelas eksperimen yang menggunakan media pembelajaran Edmodo meningkat dalam kategori sedang. Penggunaan media pembelajaran e-learning berbasis Edmodo membuat mahasiswa termotivasi kuat untuk belajar.

\section{DAftar Pustaka}

[1] Sardiman A.M, Interaksi dan Motivasi BelajarMengajar. Jakarta: PT Raja Grafindo Persada, 2006.

[2] D. P. Mahesi Agni Zaus, Rizky Ema Wulansari, Syaiful Islami, "Perancangan Media Pembelajaran Listrik Statis dan Dinamis Berbasis Android," vol. 1, no. 1, pp. 1-7, 2018.

[3] D. Pernanda, M. A. Zaus, R. E. Wulansari, and S. Islami, "Effectiveness of instructional media based on interactive cd learning on basic network at vocational high school : improving student cognitive ability Effectiveness of instructional media based on interactive cd learning on basic network at vocational hig," Int. Conf. Educ. Soc. Sci. Technol., no. February, 2018.

[4] S. Arikunto, Metodologi Penelitian Suatu Pendekatan Proposal. Jakarta: PT. Rineka Cipta., 2002.

[5] N. Jalinus, R. A. Nabawi, and A. Mardin, "The Seven Steps of Project Based Learning Model to Enhance Productive Competences of Vocational Students," vol. 102, no. Ictvt, pp. 251-256, 2017.

[6] O. Hamalik, Manajemen Pengembangan Kurikulum. Bandung: PT. Remaja Rosdakarya, 2007.

\section{Biodata Penulis}

Vinanda U'un Ayuningtyas, lahir di Madiun, 24 Juni 1988. Sarjana Sains Terapan di Jurusan Teknik Informatika Politeknik Elektronika Negeri Surabaya (PENS). Tahun 2015 memperoleh gelar Magister Pendidikan di jurusan Pendidikan Teknologi dan Kejuruan Program Pascasarjana UNESA dengan bidang konsentrasi Teknik Elektro. Staf pengajar di jurusan Pendidikan Teknik Elektro Universitas PGRI Madiun sejak tahun 2016- 2018. 